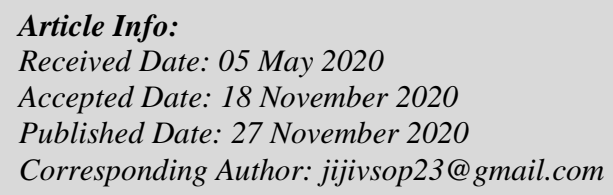

\title{
Symbolism of The Sabah Bugis Motive: Sign and Meaning: Weapon and Textile
}

\author{
Mohamad Azizie Nordin \\ Saiful Akram Che Cob \\ Faculty Art and Design, Universiti Teknologi Mara, \\ Shah Alam, Selangor, Malaysia
}

To cite this article (APA): Nordin, M. A., \& Che Cob, S. A. (2020). Symbolism of The Sabah Bugis Motive: Sign and Meaning: Weapon and Textile. KUPAS SENI: Jurnal Seni Dan Pendidikan Seni, 8(2), 1-12. https://doi.org/10.37134/kupasseni.vol8.2.1.2020

To link to this article: https://doi.org/10.37134/kupasseni.vol8.2.1.2020

\begin{abstract}
The research aims to analyse the motive of the traditional Bugis symbol and meaning in Tawau, Sabah (weapon $\&$ textile). The research is type is d descriptive qualitative approach with interviews, observation, document, and literature review. Data analysis techniques in this research are ethnography Clifford Geertz. The results of the research indicated that weapons and textiles have a philosophy and symbolic meaning of Bugis Sabah's motive. In this study, textile for Bugis Sabah has convinced symbolic meanings that are very dependent on the wearer for green color for nobility women, red color for teenager's girl, red color for married women, purple color for widows, black color for elderly and white color for assistants and shaman. Lippa Sabbe' cloth also has its meaning and philosophy. The motifs found in this Lippa Sabbe 'is Balo Tettong, Mallobang, Cobo, Balo dan Balo Renni. For weapons, the cultural value system is also an important aspect of a culture that has a concept in the lives of society. These cultural values are an important and valuable aspect of one's personality. This is also because the value of the culture is also a guideline that is significant enough for each human behavior. In culture, there are ideas and values for them to learn. In a way, they are sure to know the elements. Pamor Polobessi functions to providing content on the values of heroism (arowaenengeng); meanwhile (abbaramparengeng is meant to be wealth. Also, the authority known as (arajangeng) is placed in Polobessi.
\end{abstract}

Keywords: textile, weapon, meaning, symbol

\section{INTRODUCTION}

Bugis or Ugi is one of the ethnicities inhabiting some areas in Peninsular Malaysia and Sabah. The focus on Peninsular Malaysia lies in Johor, where most Bugis people live in the area. Meanwhile, in Sabah, Tawau is home to most Bugis people. Lahad Datu, Sandakan, Semporna, and Kunak districts are also part of the Bugis residency. In the daily life of the Bugis people, they are still bound by the norm system and custom rules that are regarded as sublime as the system is still in use, namely the emperor (pang'ade'reng). Mattulada (1985: 54) the governor regulates how one is behaving and civilized within the community. Pemeredreng system consists of the five most important elements in Bugis namely; ade' (adat), speech (trial/judgment), rapang (moral treatment and good manners emulated by society), (Christian Pelras, 1996: 190). These elements will be used in households, making a living, traveling to foreign countries, and so on. Ade' is a must-have humanitarian value that needs to exist within the Bugis people or else non-existent caste will be swallowed by the increasingly advanced modernization of today. 
Customs inherited from the ancestors in Bugis society are still practiced until today. This custom is divided into four parts, namely i) rituals to face crisis; ii) rituals for safety; iii) rituals avoiding 'malapes' or illness, and iv) rituals for thanksgiving. Through understanding, we can also see the meaning contained in the action or symbol in the ritual that can be categorized in three parts is the first one is to understand the meaning and purpose behind the symbols to be used in rituals. The second is to practice these rituals to prevent dangerous and ill omen if not done. Third, the person who performs the ritual having a different understanding of the true meaning of it (Nurhayati Djamas, 1985: 294).

The Bugis are very famous for being seafarers who have developed a maritime culture over the centuries in Indonesia. Phinisi and Lambo are the types of Bugis boats that have pastured the waters of the Archipelago, Sri Lanka, the Philippines, and Northern Australia to trade. This Bugis maritime culture not only develops sailboats and savvy sails but highs up a commercial law and sail. Halilintar Lathief (2003: 18) a written shipping law legacy is called an allopilopping adek written in Bugis lantern by Ammana Gappa in the 17th century. Bugis people are open-minded and willing to leave their homeland because they want to explore outside their homeland. The upheaval that occurred on the 16th of the year in which the war between the kingdoms led to the Bugis people wandering out of South Sulawesi. This situation can be seen through the Bugis Pagatan people on the west and south coast of Borneo, in the east and north coast areas of Sumatra and the west coast of the Malay Peninsula. The growing number of Bugis people in selected Malay states is not only due to the turbulence in their homeland, but because Bugis people like to travel and sail to explore new worlds (Mohd Akbal Abdullah \& Abdullah Sulaiman, 2005: 3). Here we can see that the migration of Bugis in Sabah, Malaysia, can be addressed through the Tawau district. Bugis migration because major economic factors as Tawau was the place where the Japanese cultivate economic activities and political matters, which led the Bugis to Tawau to find a better life. Moreover, the Bugis already had a settlement in Tawau, Sabah during the entourage led by Puado around the 1880s when the Dutch and British previously occupied it.

A value expressed by the Bugis is Siri, either from the Bugis people who reside in South Sulawesi or those who migrate to the Borneo Islands and some Malay Archipelago. Siri is also used as a principle and is appreciated by cultural values inherited by the ancestors of people called as 'pappaseng'. The six main values of the Bugis people are 'lepu' (honesty), amaccang / acca, astinajang (fairness), getting stronger, reso (hard work), and Siri (shame/self-esteem). Today's Siri is still being practiced because it is the identity of the Bugis community and is the main values today. The Siris should be defended for being a nation's heritage that needs to be preserved so that it is not tainted by others. An assertive approach will be taken to restore one's self-esteem if someone is humiliated. Manurung is considered the most perfect body because of its white blood. According to Nur Alam Saleh (2004: 23), the Siri is abstract because it cannot be seen through the naked eye but can only be felt by one. H.M. Laica Marzuki (1995: 48) also the Siri means dignity, self-esteem, and honor, which is a key-value to the lifestyle of Bugis people.

The weapon is popular for Badik and Kris because of the Bugis. Badik also has his own interpretation of the culture of Bugis, which they have believed since their ancestors' times. Sword is one of the traditional cultural identification weapons of the Malaysian peoples of the world, including Bugis, Makassar, Mandar, and other northern tribes as special weapons, as well as other ethnic groups scattered in various other areas. Panre Bassi is a nickname for the Bugis culture for people who profess to be blacksmiths on a regular basis. Badik or kawali is typically made by Panrita Bessi (in the form of an iron expert), who starts by searching for raw materials in the process of making it, which is then carried out by magical filling via the ritual process of compiling traditional weapons.

Silk fabrics have distinctive colors and different patterns as the wearer will feel comfortable with the use. Lippa is a unique checked pattern. Silk in Bugis is called "sabbe" which is a beautiful sarong and is the result of the Bugis hand. On the day we can see that this sarong is still worn by the Bugis for maintaining the culture. Besides, this sarong is also worn in traditional ceremonies and 
traditional weddings and festivals (Rahman, 2009). This silk has its own unique colors and shapes such as small squares and geomorphic forms. This is also a distinctive pattern called in Bugis language is a "balo" which is something its decoration or color (Tahara, 2013). These patterns also have their symbols and have meaning, philosophy, and aesthetics. These silk fabrics also have a variety of special motifs for consumers as each of these sarongs has its color and every symbol or motif that symbolizes the culture of the Bugis itself. The meaning of the sarong is also very valuable because when someone wants to sell the price is higher. After all, the silk cloth is different from the unique and luxurious fabrics and the shine and tenderness Soedarso, (2006:101).

\section{PROBLEM STATEMENT}

The problem lies in the development of Bugis motifs, which have been mixed, so the pattern of the 'renni' and the 'hole' has been intruded with the other motifs. The Renni Balo motif is a vertical motif while the Balo Lobang motif has a motif that has a thick line. Adults are also free to create patterns and strive to create new ones (Tawau Regional Library P.7775, 91008 Tawau).

The preservation of a culture or the preservation of architecture here means we care to repair the recovery and rebuilding of the long-established, long-standing architecture (Ali Emran, 1990). Retention also plays an important role because it takes the steps of recovery, consolidation, adaptation, and so on. (Fieldan, 2000; Paiman Keromo, 2006; Kamarul Shahril, 2010).

Efforts to promote Bugis culture in Sabah are actively carried out by the Malaysian Unity of Malaysian Bugis Unity (RBB) Society. Sandakan PRBM division deputy chairman, Sundusin Nganro, 41, said through the association, various efforts were made including gathering members of the Bugis community, participating in cultural activities, and organizing traditional and cultural programs. As a result of the changing times, he said, the customs of the Bugis community are not exempt from being eroded like other tribes in Sabah including in terms of speech, food, way of life besides practice in the the occasion of a wedding, weddings in particular. "This may be because most Bugis communities have already undergone the assimilation process, thus affecting the customs and culture itself, including the interdependence factor." Hence, various efforts have been taken to ensure that essential elements in the lives of the Bugis community are not just buried, he said. (Berita Harian, 2015)

\section{RESEARCH OBJECTIVES}

- To study the motive of the traditional Bugis symbol and meaning in Tawau, Sabah (weapon $\&$ textile).

- To analyse the motive of the Bugis symbol in Tawau, Sabah (weapon \& textile).

\section{SIGNIFICANCE OF RESEARCH}

One of the significances of this study is that the Bugis culture found in Tawau, Sabah can be prioritized. Through this approach, the younger generations will certainly be able to know and understand the Bugis culture in Tawau, Sabah on a deeper level. The generation of today will show more interest in the Bugis culture itself with all the motif symbols found in the materials such as weapons and textiles as it is one of the uniqueness to learn and be proud of. In this way, it will surely give beneficial knowledge that can be passed to every generation that is coming so not to leave the culture behind.

This study also contributes to the appreciation of Bugis culture found in Tawau, Sabah. The research is aimed to gain an appreciation and attract interest among the people so that the Bugis culture is valued and not cease to exist. With this, the research could also attract researchers from the 
Western to learn more about the Bugis culture and at the same time contribute to the community in Tawau, Sabah, including the government Sabah and young generations. Research of the community who travels to Sabah receives less attention, therefore this research and the researcher's studies, which is conducted will include the Bugis aspects found in Sabah.

\section{RESEARCH METHODOLOGY}

\section{General Qualitative Research}

This part clearly explains the research methodology used in the study, which is to understand and examine a symbol motif found in Sabah Bugis itself. This chapter will also discuss how the symbol of the Bugis motif will be categorized as well as the concepts involved in the investigation, which is more specific to the symbols in the understanding of symbolic anthropology. This approach is also used because these symbols are abstract in that they are considered to be related to the knowledge system in human life. According to Clifford Geertz (1981) this culture is also one of the most effective aspects as it is treated purely in symbolic form.

\section{Research Flowchart}

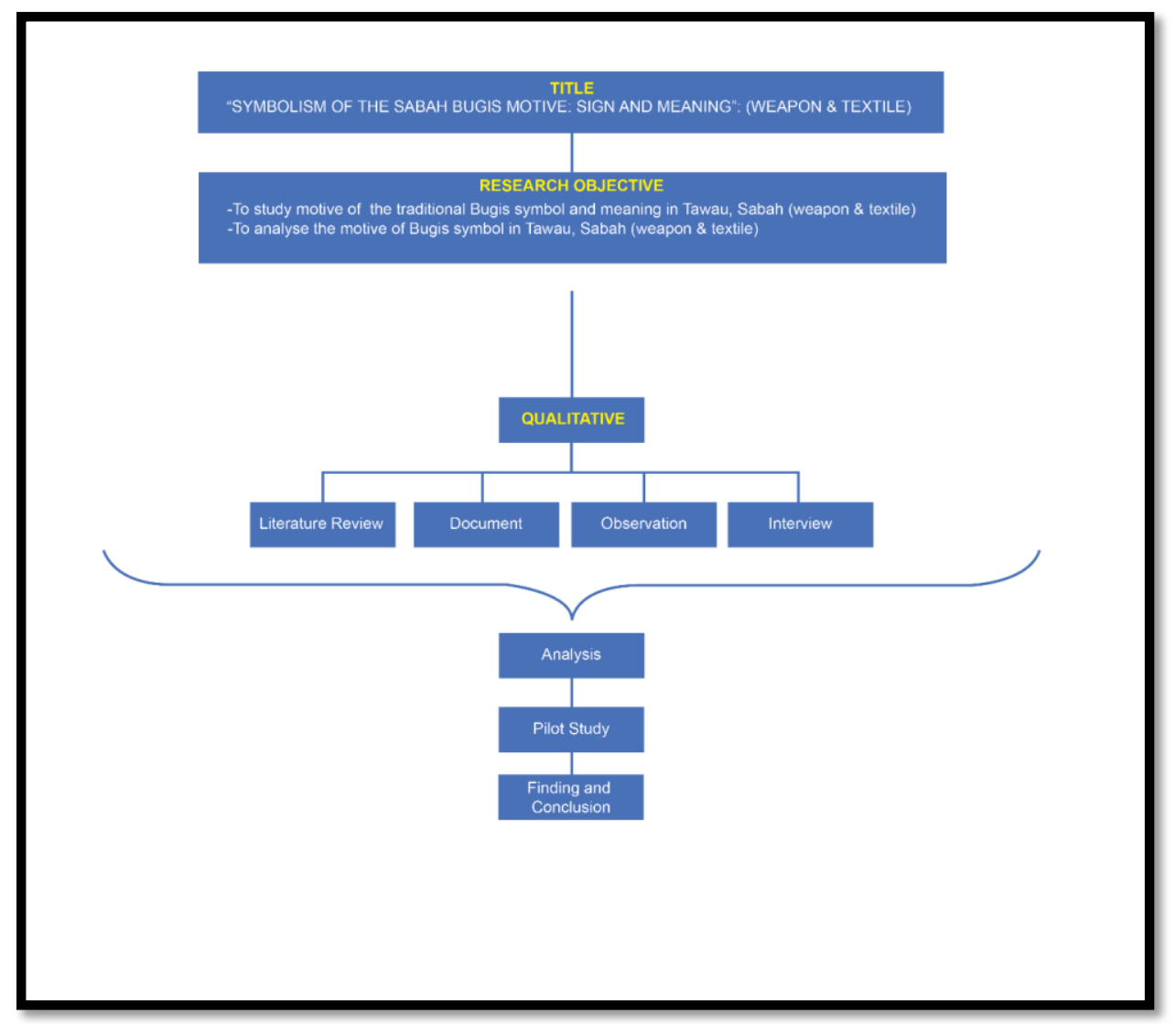

Figure 1: Research Flowchart

This design also allows the researcher to pay attention to the processes in the category of Bugis motif found in Sabah. The researcher will also understand the process as the researcher will understand the situation in a given environment (Creswell, 2003). The research of this explanation and observation would therefore be capable of providing the researcher with certain questions with insight. Interviews, observations, record analysis, and literature reviews are the research methods used 
to classify them. The study will also be an in-depth study, which will expand on the principle as the research will be conducted in the inductive data collection process.

At the end of this study, the researcher will also present processes such as the category of Bugis motifs in Sabah in terms of weapons and textiles. Also, this category of motive symbols will be used to give its meaning in the Bugis motif symbol. Therefore, the submissions will also be made based on all the studies carried out as well as the systematic significance of this study area.

\section{Research Instrument}

\section{Visual Documentation}

Visual documentation and observation are also used to keep as data collection tools. The weapons and textiles of the Bugis themselves can be taken from visual motifs. All of these available motif symbols will be analysed in greater depth. The existing motif symbol will be used and recorded to interpret the existing design. The existing documents will work because they are used in the primary data and are illustrated in the research that is being conducted. (Merriam, 1998). The results of the study will be reviewed and discussed with the experts involved. Visual documentation used by the researcher is books, report, journals, and artifact.

\section{Photography}

Photography has been a form of art from the beginning, its approach and tool for analyzing society and an important journalistic instrument Becker (1974). In the early nineteenth century, photography and sociology originated with Comte's work on sociology at about the same time. Three common approaches of dealing with photos may be articulated by social science, journalism and art photography. Within a transdisciplinary context that defies methodological and theoretical limits, photographic study seems to exist Chilton \& Leavy (2014).

Collier \& Collier (1990) photography image can reveal sensitivity and and idea of native people. Photography is a form of technology that is getting more advanced because today, photography is easy to use and is cheap. Photography plays an important role in this research because it can present complex overviews and strong evidence. Surely, with this method of using photography technology, it can help the researcher analyse symbols. Photography is used for taking visual esteem to the weapons and textiles which is available in the Sabah Bugis only.

Visualization is also an important aspect because it can express visuals directly and give ideas through various techniques to understand the issue presented by the researcher. Visualization also helps to give the researcher an expression of the study conducted. The study conducted must have basic practices like the expertise in visuals, interpretations, cooperative studies to gain information, and produce new ideas. This way this visual will be able to help researcher know the elements and shapes of symbols that are available in the weapons and textile in Sabah only. 


\section{Conceptual Framework}

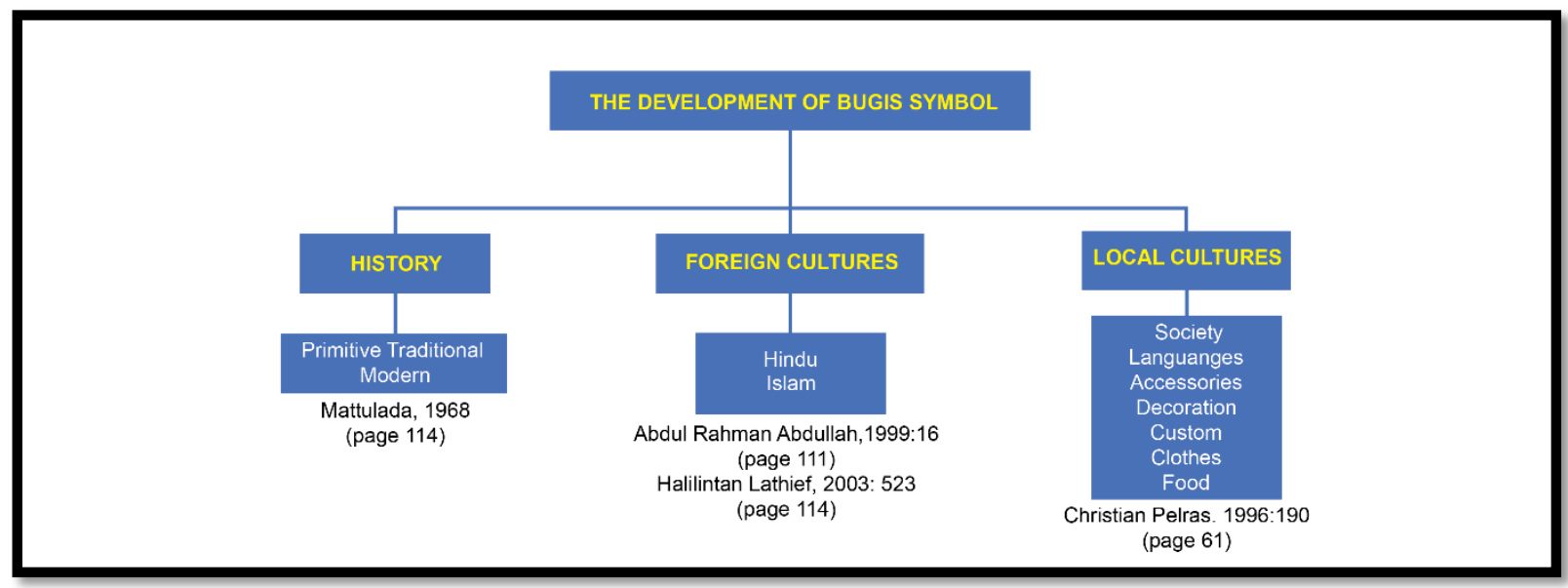

Phase 1- Development of Bugis Culture

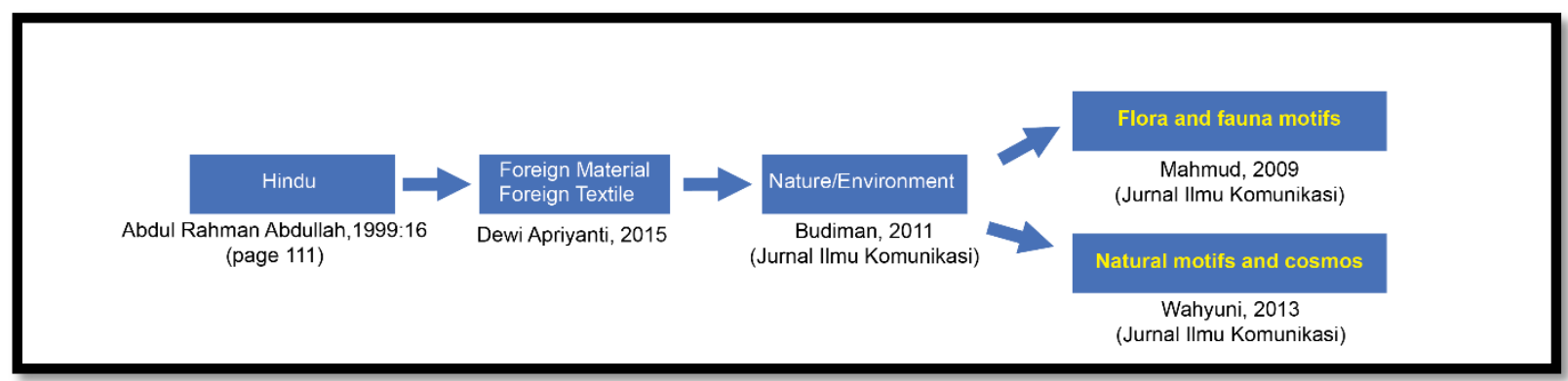

Phase 2- External and Internal Influences

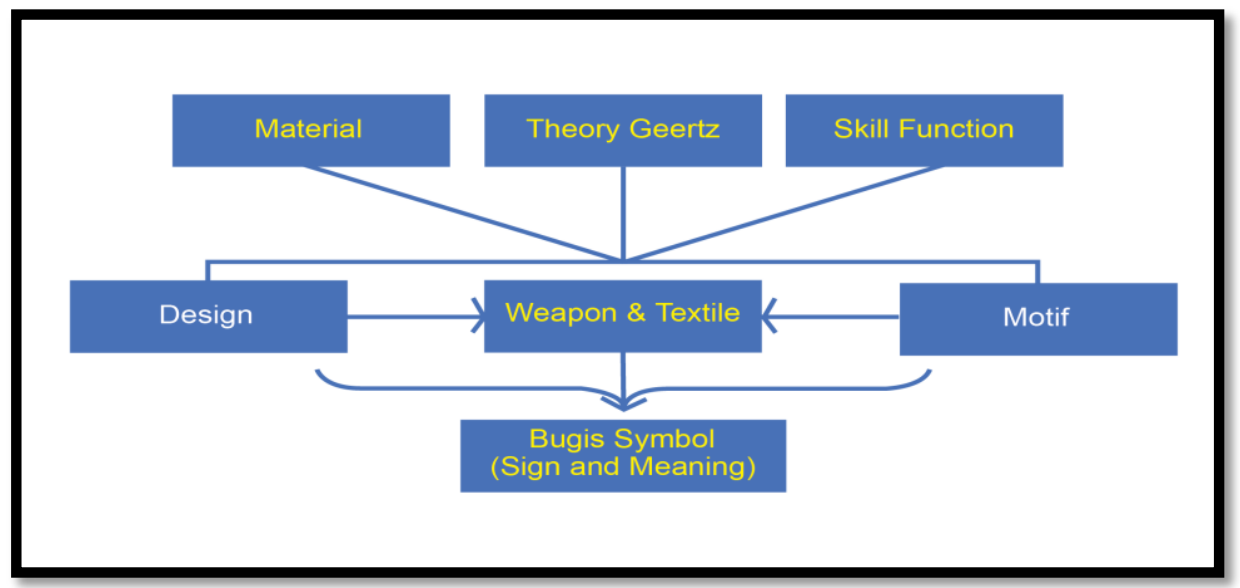

Phase 3 - Analysis Bugis Symbol

\section{Phase 1- Development of Bugis Culture}

In this first phase here, we can see that; this analysis is done in knowing the general development of the Bugis culture. Here we can see that the variables used are history, foreign influences, and the social life of the Bugis people themselves. The history of Bugis here we can see the context of this study has a primitive in which they live in the perspective of modern society. Factors that we can see traditional and modern. Also, before the Bugis entry into Islam, they are influenced by the foreign culture of the Hindu religion. The third variable that we can see is where the Bugis people themselves do activities in their daily lives such as customs, rituals, and values until today. 


\section{Phase 2- External and Internal Influences}

Among the external influences found in the Bugis itself, i.e. the Hindu as described in the diagram. The next variable is the external influence in the materials and textile of Bugis. However, the elements of flora and fauna, Cosmos are also found in weapons and textile the Bugis people who are also involved in the Bugis holdings known as the series '. Besides, there are also animism elements in the Bugis accessories worn by women when there is a marriage known as Simpolong Tattong.

\section{Phase 3- Analysis Bugis Symbol}

For Geertz, the culture is closely related to the symbol or symbol. With this symbol, he said, people mutually convey thoughts, feelings and communicating. Culture does not happen to be familiar but based on the interpretation or interpretation of society towards an experience. Geertz also stated that a system in the culture itself would have a symbolic meaning which it would also play their feelings and can make the assessment itself. Besides, symbols will also be able to communicate with each other where it will also provide knowledge in culture. Subsequently, according to Geertz, he stated that the culture was also the symbol of the need to be translated in more.

\section{ANALYSIS AND FINDING}

\section{Bugis Daily Clothing and Jewellery}

Each of the Bugis tribes comprises of a modest group of people who wear these traditional clothes made from barks and are worn daily. This Bugis attire is a very important aspect of the nation and has a distinctive view of the life of a society based on the different types of clothing. From a clothing standpoint, we can identify a particular race or ethnicity because every garment worn symbolizes a nation. There are also some of the features that symbolize the clothes worn by the Bugis either from the ritual form, symbol, color, or the style of clothing worn by the Bugis themselves.

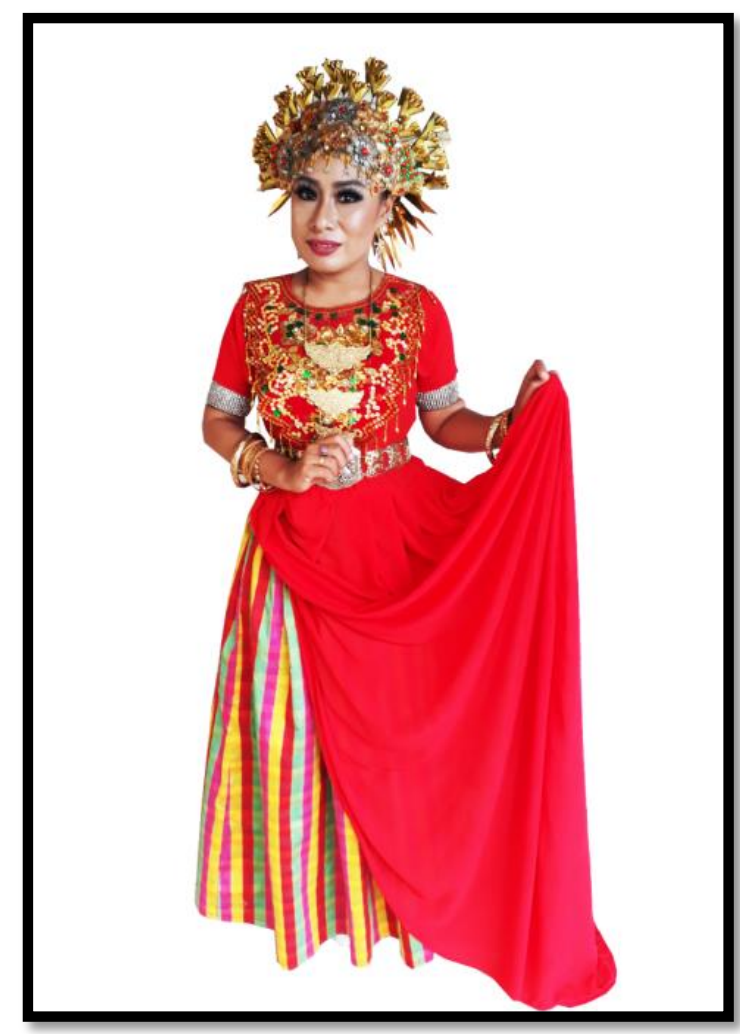

Figure 2: Bodo Clothing 
In these Bugis dresses, there are some categories according to age set and have distinctive meaning. For infants, up to four years of age wear this apparel within the Bugis group. For these peers, they have special apparel in which they will be wearing a green shirt accompanied by a karawik or a salawik. Additionally, the women will wear a jempang, while the men wear Laco-Laco. Both men and women also wear Simak-simak that is made of gold or silver that functions to protect them from a cold that is accompanied by a sheath cover known as ileko or nileko for 40-days. At the age of four, girls will wear a sheath known as a mattope koja tope (worn like a skirt). For boys, they will wear white tope and songkok provided as jewellery.

\section{Tribal Customs in Sabah (Labbu Shirts)}

The Bugis people often wear apparel like the Bodo shirt (short shirts) and Lipa Sabbe (silk casing) during significant events like marriage and funeral, especially among the women. This Bodo shirt was named by the Makassar people as a means that the shirt is short or known to be short. The Bugis people have also called the Bodo shirt as the Ponco shirt. There is a possibility that this shirt is called short shirts by looking at the arm sleeves.

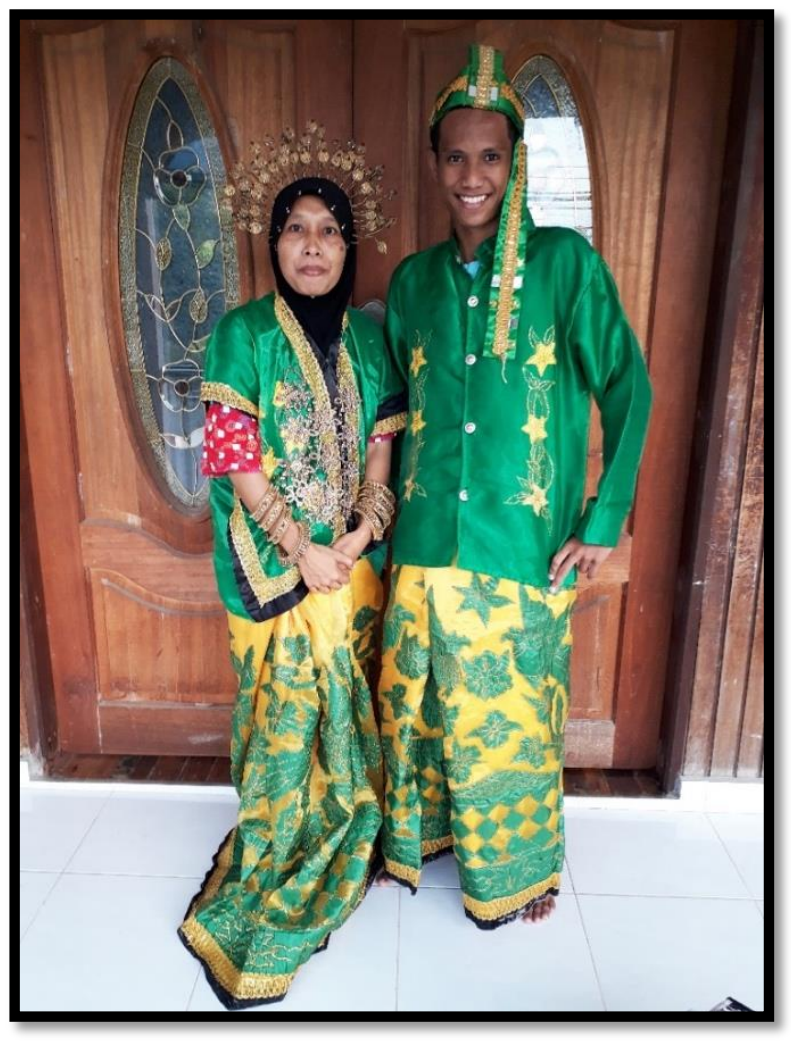

Figure 3: Men and Women's Clothing

During the days before starch was used in the making of the apparels, starch was used in rice porridge or acid porridge. There are some ways in which to make a mug shirt; first, you get a shirt, then soak it in starch so that the study is evenly balanced and then take the stone as a weightlifting dish and pat it again. Having dried up the Bodo shirt, it is smoothening and ironed into a neat look. After that, the bodo shirt will be removed and folded or shaped according to the requirement of the application. According to the notes, the name Bodo shirt was first known as bodo, waju tokko (Bugis), Tokko shirt (Makassar) and waju ponco (Bugis) may be due to several meanings of the long-arm labbu shirt. On the other hand, the Bugis people wear the Bodo to an armchair's length. When the shirt is worn then the shirt will look similar.

The short Bodo shirt will only be worn by girls or teenagers such as dancers and the bride's maids equipped in jewelry. It is different from a wedding dress because here we can see that the 
wedding dress is adorned with paceppa and patenre kind of decoration on the edge. Meanwhile, Bodo shirts influenced with weaponry were usually worn by adult male. In terms of development, it is seen less prevalent among the Bugis because of the clothing shape of a rectangular form on the second side of the part of the division that is not sewn. To wear them, the arms are slide directly into the arm sleeve while the top was hollowed out to include the head, known as the bodo neckline.

\section{Bugis Weapons (Kris, Badik, and Sword)}

The cultural value system is also an important aspect of a culture that has a concept in the lives of society. These cultural values are an important and valuable aspect of one's personality. This is also because the value of the culture is also a guideline that is significant enough for each human behavior. In culture, there are ideas and values for them to learn. In a way, they are sure to know the elements.

The review of values among the Bugis community is a past time where it is related to the Bugis weapons of Polobessi. This is because it is to regain the trust and self-esteem of the Bugis people. Pamor Polobessi functions to providing content on the values of heroism (arowaenengeng); meanwhile (abbaramparengeng) is meant to be wealth. Besides, the authority known as (arajangeng) is placed in Polobessi. These three values are usually found placed in Bugis estates such as kris, badik, swords, and spear. Polobessi in the Bugis language means a fairly noble inheritance or iron weapon that is a weapon for the Bugis. Also, the purpose of Polobessi is similar to the word Tosanaji that brings the same meaning as a noble estate of iron weapon.

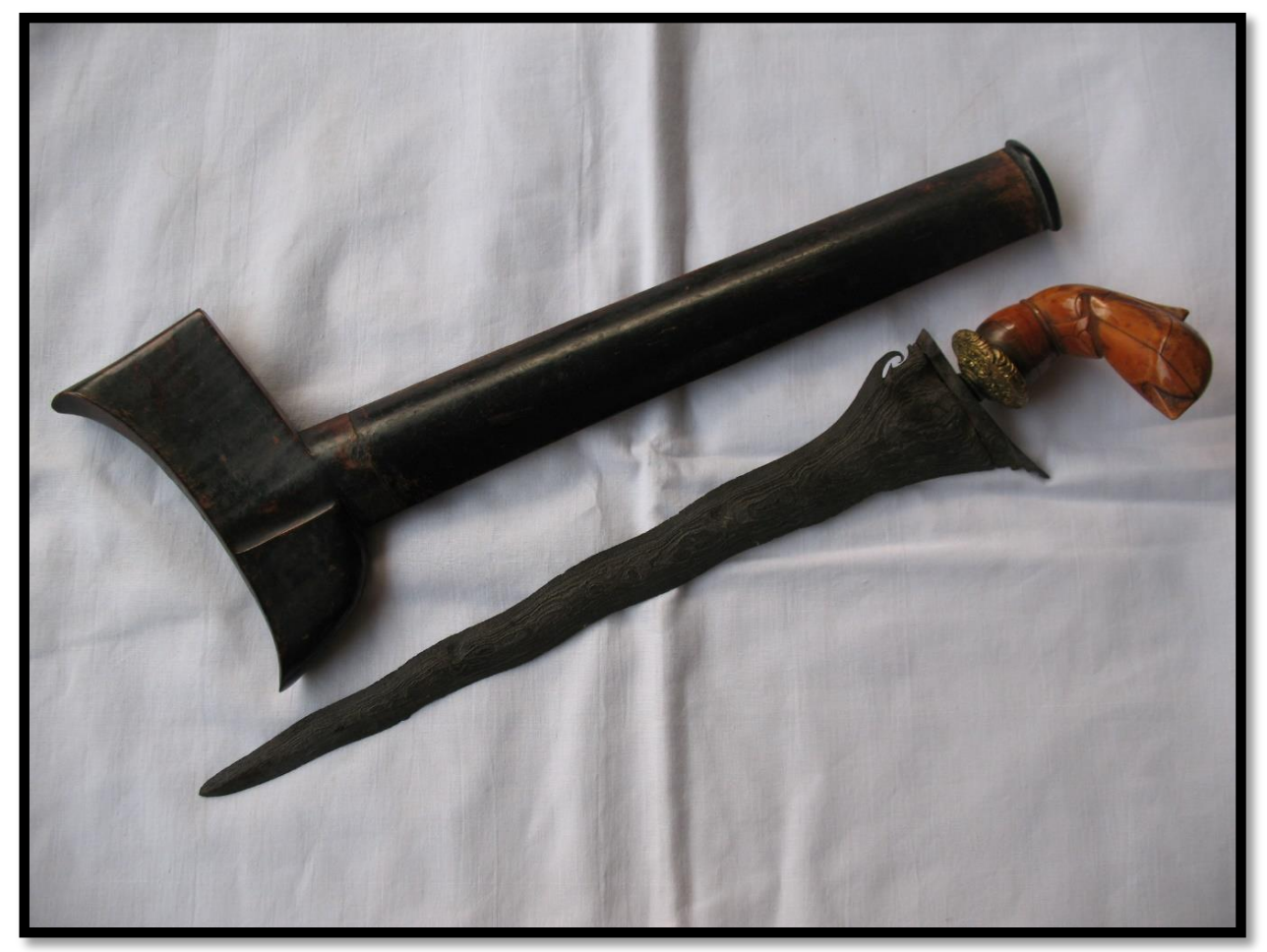

Figure 4: Kris Bugis

Sisi' or known as appesisikeng is also the traditional knowledge of the Bugis people, which is the reason for knowing good and bad. The side of Polo Bessi is a good and bad disc in a weapon of this estate. This we can see that the motifs and the signs of visuals are available. In addition, here we can also see that through the carvings (suke) that a person owns this Bugis weapon. Motifs, visual signs and benchmarks can also be found to be good and bad in a particular weapon. To knowing if the weapon is good is not based on its sides but is based on the were, which is guided by Allah SWT. 
Before we explain deeper about this symbol, we must know that the word symbol is derived from the Greek word which means token. It is a sign or feature that wishes to convey a thing to people. In addition, here we can also see that the sign and good in this Bugis estate is also a sign that the meaning is to represent or state something else. The side is also one of the Bugis inheritance arms referred to as sisi or appesisikeng. Were' is also a living point where the Bugis people work hard tirelessly. This is to be able to change someone's fate or circumstances in good or bad conditions. As previously mentioned, people who work hard, without stoping will receive guidance from Dewata (resopa na tinulu na temmangingi, malomo naletei pammase Dewata). The attitude in this hard work is also a principle of hope to continue their work.

\section{RESULT AND DISCUSSION}

Clothing is also a cultural symbol as it is also a progression in a culture where it will grow by age circulation. It is also a symbol of the community as it is a heritage and a reflection of the Bugis itself as well as traditional custom clothing available in Sabah. Clothing is also a heritage of the forefathers where it has distinctive uniqueness and has its own distinct meaning. Sabah's traditional Bugis attire should be passed down as it is a symbol of wealth. When a society does not take care or concern about their culture, the culture will be forgotten and eventually cease to exist. The Bugis culture promotes attractive clothing and outfits, and it becomes a source in helping the economy as it could attract the attention of people from foreign countries. This part of the Bugis people culture has become increasingly firm and popular. Its popularity is influenced by some factors that is deemed significant, which makes this natural culture to be more resilient in the wake of the changing eras and within the society. Additionally, this could lead to the expansion of the Bugis culture. In this modern, most of the young ones today are spending their time with social media or surfing the internet causing the spirit to keep this culture to diminish. They are prouder to be wearing branded clothes from outside of the country and replicate the western clothing with distinctive styles. This would make them to perceive that the traditional customs and styles are outdated and traditional because today's clothes are more stylish and trendier.

The Tawau International National Festival (FKAT) is a festival that presented the Sabah's Bugis ethnic culture. The Bugis Community Association of Sabah will also take part in the festival where the Sabah Bugis will showcase the clothes, foods, weapons, and traditional tools. Tuan Haji Pondren Nawa who headed the Sabah Bugis Community Association Committee leads Sabah Bugis Community. Here we can see this Sabah Bugis Community Association has also managed to promote the Bugis culture itself. They can also find other ethnicities in Sabah. It is because Sabah is a diversified tribe. The festival will also be held once a year to promote culture in every ethnic group in Sabah. Besides, according to the president of Sabah Bugis Community Association, YBHG. Osman Haji. Jamal, the PKBS existed to introduce to the other ethnics of Bajau and Dusun to the Sabah Bugis community. Also, in terms of language, clothing, foods, and weapons are similar to Bugis found in Indonesia but there are other differing criteria.

Clothing is also a cultural symbol as it is also a progression in a culture where it will grow by age circulation. It is also a symbol of the community as it is a heritage and a reflection of the Bugis itself as well as traditional custom clothing available in Sabah. Clothing is also a heritage of the forefathers where it has distinctive uniqueness and has its own distinct meaning. Sabah's traditional Bugis attire should be passed down as it is a symbol of wealth. When a society does not take care or concern about their culture, the culture will be forgotten and eventually cease to exist. The Bugis culture promotes attractive clothing and outfits, and it becomes a source in helping the economy as it could attract the attention of people from foreign countries. This part of the Bugis people culture has become increasingly firm and popular. Its popularity is influenced by some factors that is deemed significant, which makes this natural culture to be more resilient in the wake of the changing eras and within the society. Additionally, this could lead to the expansion of the Bugis culture. In this modern, most of the young ones today are spending their time with social media or surfing the internet causing 
the spirit to keep this culture to diminish. They are prouder to be wearing branded clothes from outside of the country and replicate the western clothing with distinctive styles. This would make them to perceive that the traditional customs and styles are outdated and traditional because today's clothes are more stylish and trendier.

\section{CONCLUSION AND RECOMMENDATIONS}

The benefit of preserving the Bugis community is to keep it from being forgotten and lost in the ages for future research on Bugis. In order to be inherited by future generations, this Bugis culture should be retained. It is also necessary to prevent Western culture, which can damage our national traditions, from affecting society. With the negative impact they have the presence of Western culture in the culture of Bugis is feared to affect the next generation. This is also important for the prevention of. In this way, it is certainly important that we maintain a culture of self-reliance so that Western culture cannot pollute the minds of the younger generation who will be the future leaders of the nation and the ever-increasing modernization era. Furthermore, the interests or opportunities for the Malay community of Bugis Sabah are involved with the country's economic resources such as culture and tourism. Here we can know Sabah is a well-known state of the island. Culture is one of the most important assets of the country's tourism industry.

This study also contributes to the appreciation of Bugis culture found in Tawau, Sabah. The research is aimed to gain an appreciation and attract interest among the people so that the Bugis culture is valued and not cease to exist. With this, the research could also attract researchers from the West to learn more about the Bugis culture and at the same time contribute to the community in Tawau, Sabah, including the government and non-government organizations. Research of the community who travels to Sabah receives less attention, therefore this research and the researcher's studies, which is conducted will include the Bugis aspects found in Sabah.

Besides that, the contribution of this research can be used by the next researcher because the efforts of the researcher can be utilized in learning more of the Bugis motif symbols found. In this way, it is certain that the symbols are preserved and encourages the interest of the people from outside to learn more of the Bugis symbols found in Tawau, Sabah. Next, the documentation of the heritage of Bugis can be used and maintained so that the generations recognize their culture and practice it within themselves. This is because the cultural heritage is of utmost importance that must be upheld so that it will not disappear along the time of era modernization. To avoid misconception about Bugis in Tawau, Sabah also presents the significance of this research. This is because many people consider the Bugis people as pirates. Hence, this research will explain of the coming and immigration of the Bugis within the Malay clump and in my state, which is Sabah.

\section{REFERENCES}

Abdullah, N., \& Jambi, J. (2017). Pusat-Pusat Pemerintahan Kesultanan Melayu Johor Membina Penempatan Awal Orang Melayu Di Sepanjang Sungai Johor. Jurnal PERADABAN, 10(1), 38-61. doi: 10.22452/peradaban.vol10no1.3

Becker, H. (n.d.). Photography and Sociology. Retrieved November 18, 2020, from https://repository.upenn.edu/svc/vol1/iss1/3/

Collier. (n.d.). Retrieved November 18, 2020, from https://www.merriam-webster.com/dictionary/collier

Gendang. (n.d.). Retrieved from https://halilintarlathief.blogspot.com/.

Goodlet, K. (2010). Tawau: the making of a tropical community. Kota Kinabalu: Opus Publications.

ILBS - Malaysian Publisher of Law Books. (n.d.). Retrieved from http://www.malaysialawbooks.com/.

Iqbal, U. (n.d.). SEJARAH PERKEMBANGAN PELABURAN JEPUN DI BORNEO UTARA SEBELUM

PERANG DUNIA KEDUA. $\quad$ Retrieved from
https://www.academia.edu/8308992/SEJARAH_PERKEMBANGAN_PELABURAN_JEPUN_DI_BO RNEO_UTARA_SEBELUM_PERANG_DUNIA_KEDUA. 
La Galigo International Seminar and Festival (Barru, South ... (n.d.). Retrieved from https://www.researchgate.net/publication/250257174_La_Galigo_International_Seminar_and_Festival _Barru_South_Sulawesi_15-18_March_2002.

Lim, L., Ang, K., Mahani, M., Shahrom, A., \& Md-Zain, B. (2010). Mitochondrial DNA Polymorphism and Phylogenetic Relationships of Proto Malays in Peninsular Malaysia. Journal of Biological Sciences, 10(2), 71-83. doi: 10.3923/jbs.2010.71.83

Marzuki, H. L. (1996). Aspek Hukum Administrasi dari P.T. Jurnal Hukum \& Pembangunan, 26(3), 212. doi: 10.21143/jhp.vol26.no3.509

Mattulada. (n.d.). Latoa: satu lukisan analitis terhadap antropologi-politik orang Bugis. Retrieved from https://books.google.com/books/about/Latoa.html?id=dG5oNwAACAAJ.

Nurhayati Djamas - Wikipedia bahasa Indonesia ... $\quad$ (n.d.). Retrieved from https://id.wikipedia.org/wiki/Nurhayati_Djamas.

Said, N. (2014). The Significance of al-Ghazālī and His Works for Indonesian Muslims: A Preliminary Study. Studia Islamika, 3(3). doi: 10.15408/sdi.v3i3.799

Soedarso Sp. 2006. Trilogi Seni, Penciptaan, Eksistensi, dan Kegunaan Seni”. Yogyakarta: ISI Yogyakarta The adventures of John Smith in Malaya, 1600-1605. (2018, November 9). Retrieved from https://www.worldcat.org/title/adventures-of-john-smith-in-malaya-1600-1605/oclc/6007406.

The Bugis. (2018, November 10). Retrieved from https://www.worldcat.org/title/bugis/oclc/247435344.

Wanharrun91. (n.d.). Andaya BW and Andaya LY 1982 A history of Malaysia Macmillan Press London Asean. Retrieved from https://www.coursehero.com/file/p3c99so/Andaya-BW-and-Andaya-LY-1982-Ahistory-of-Malaysia-Macmillan-Press-London-Asean/. 